\title{
Feasibility Study of High Strength with Fly-Ash Based Geopolymer Concrete
}

\author{
Mr. Ajay Xavier ${ }^{1}$, Mr. Sanket Bhagat ${ }^{2}$, Mr. Jayesh Patil ${ }^{3}$, Mr. Parag Jadhav ${ }^{4}$, Mr. Ajinkya \\ Raut $^{5}$, Dr. Buddharatna J. Godboley ${ }^{6}$ \\ ${ }^{12345}$ UG Students, Department of Civil Engineering, St John College of Engineering \& Management, Palghar \\ ${ }^{6}$ Associate Professor, Department of Civil Engineering, St John College of Engineering \& Management, Palghar
}

Received on: 26 April,2021 Revised on: May 29, $2021 \quad$ Published on: 31 May 2021

\begin{abstract}
Concrete being the core element used for the construction across the world has a main ingredient in it called 'cement'. Production of cement leads to larger amount of carbon dioxide in the environment with a staggering amount $8 \%$ of carbon dioxide annually, on the other hand there is still increase in significant number of construction projects day after day which leads to more demand of cement. Keeping the fact protection of environment into consideration there is an immediate need of an alternative material to cement which will have same properties of cement and of course which can help to achieve environmentally friendly construction. One material is geopolymer concrete. Geopolymer concrete uses alumina silicate rich sources as binder instead of ordinary cement. It also uses different additives like industrial by-products which has encouraged an increase in workability, compressive strength, durability and minimization of effects of temperature variation. Geopolymer concrete is an innovative material which is $100 \%$ cement free. Geopolymer concrete is necessity for the future of construction industry and for a sustainable environment.
\end{abstract}

Keywords- Geopolymer, Alumina Silicate, environment friendly, compressive strength, durability.

\section{1- INTRODUCTION}

$\mathbf{T}$ here is an increase in manufacturing, and transportation sectors due to population growth and urbanization. Natural landscapes are transformed by humans in large proportions across the earth. Result of this continuous development has led to construction industry being one of the largest across the world. Concrete being one of the most abundantly used material across the construction industry possess cement as the core ingredient in its mixture. Studies have indicated cement manufacturing alone accounts for about $8 \%$ of the carbon dioxide emissions across the world, there is a need to protect the environment from being affected further by the emissions from the construction industry. As such there is an immediate need to resort to alternative materials to achieve environment friendly construction. One such material that has been in use for more than a decade is geopolymer concrete. The geopolymer concrete technology proposed by Joseph Davidovits ensures efficient application of By-products as an alternative material to the Portland cement.

The aim of the project is to study the influence of parameters such as alkaline solution to binder ratio, curing condition on compressive strength of fly ash based geopolymer concrete at various ages. The objective of this project can be paraphrased as a normal cement contains high amount of (silica and alumina), the usage of cement is increasing day to day worldwide. Hence, alternative innovative material should be used which is fly ash. Fly ash constitutes of high number of $\mathrm{Si}-\mathrm{Al}$ materials. Since fly ash is a waste material and can be reused. So, this paper focuses on the effect of alkaline solution to binder ratio, concentration of sodium 


\section{International Journal of Innovations in Engineering and Science, www.ijies.net}

hydroxide solution and curing conditions on fly ash based geopolymer concrete and to determine the compressive strength of fly ash based geopolymer concrete at various ages such as 7 days, 14 days and 28 day.

\section{II- OBJECTIVES}

- To develop mixture proportioning process to prepare Geopolymer concrete using Fly ash, Alkaline liquids, coarse aggregate and fine aggregate.

- To identify and study the effect of salient parameters such as;

1. Ratio of sodium hydroxide to sodium silicate solution.

2. Alkaline liquid to fly ash ratio.

3. Molarity of sodium hydroxide.

4. Water to Geopolymer solids.

- To study effects of water on Geopolymer concrete and its Durability

\section{III- MATERIALS AND TESTS}

For current project work various materials like Coarse aggregate and fine aggregate are collected. We conducted various tests on the above-mentioned materials in laboratory.

\subsection{Fly Ash (Class- F)}

For this project work the obtained fly ash is from Adani Thermal Power Station, Dahanu through Sai Yash RMC plant- Wada, Palghar.

Table 1. Chemical composition of fly ash

\begin{tabular}{|c|c|c|}
\hline $\begin{array}{c}\text { Sr. } \\
\text { No }\end{array}$ & Name of The Chemical & $\begin{array}{c}\text { \% by } \\
\text { weight }\end{array}$ \\
\hline 1 & Sulfate $\left(\mathrm{SO}_{4}\right) \%$ by mass & $1.24 \%$ \\
\hline 2 & $\begin{array}{c}\text { Magnesium Oxide }(\mathrm{MgO}) \% \text { by } \\
\text { mass }\end{array}$ & $0.91 \%$ \\
\hline 3 & $\begin{array}{c}\text { Titanium Dioxide }\left(\mathrm{TiO}_{2}\right) \% \text { by } \\
\text { mass }\end{array}$ & $0.42 \%$ \\
\hline 4 & $\begin{array}{c}\text { Ferric Oxide }\left(\mathrm{Fe}_{2} \mathrm{O}_{3}+\mathrm{Fe}_{3} \mathrm{O}_{4}\right) \% \\
\text { by mass }\end{array}$ & $4.17 \%$ \\
\hline 5 & Calcium Oxide $(\mathrm{CaO}) \%$ by mass & $6.20 \%$ \\
\hline 6 & Alumina $\left(\mathrm{Al}_{2} \mathrm{O}_{3}\right) \%$ by mass & $20.21 \%$ \\
\hline 7 & Silica $\left(\mathrm{SiO}_{2}\right) \%$ by mass & $64.80 \%$ \\
\hline 8 & Loss on Ignition $(\mathrm{L} 01) \%$ by mass & $1.70 \%$ \\
\hline
\end{tabular}

\subsection{Coarse Aggregate}

Coarse aggregate having nominal size $20 \mathrm{~mm}$ were used and different taste were performed and the result are tabulated as below.

\begin{tabular}{|c|c|}
\hline Properties & Value obtained \\
\hline Specific gravity & 2.83 \\
\hline Fineness modulus & 7.1 \\
\hline Water absorption & 1.94 \\
\hline
\end{tabular}

\subsection{Fine Aggregate}

Good quality zone-I fine aggregate were used. The different tests for physical properties of fine aggregate are carried out in the laboratory and results are tabulated below.

\begin{tabular}{|c|c|}
\hline Properties & Value Obtained \\
\hline Specific gravity & 2.69 \\
\hline Fineness modulus & 3.5 \\
\hline Water absorption & 3.04 \\
\hline
\end{tabular}

\subsection{Alkaline Liquids Activators}

The alkaline activator used in geopolymerisation is a combination of sodium hydroxide $(\mathrm{NaOH})$ to prepare $10 \mathrm{M}$ and $14 \mathrm{M}$ solution and sodium silicate $\left(\mathrm{Na}_{2} \mathrm{SiO}_{3}\right)$ which is directly available in liquid form was considered for this study.

\subsection{Super Plasticizer}

Dispa-Ret SPR 485 is a strong slump retaining super Plasticiser based on Naphthalene Sulphonates with selected polymer. Amount used was $2 \%$ of total quantity of Fly ash in Kg.

\section{IV- MIX DESIGN}

\begin{tabular}{|c|c|c|c|}
\hline Sr no & Material & $10 \mathrm{M}\left(\mathrm{kg} / \mathrm{m}^{3)}\right.$ & $14 \mathrm{M}\left(\mathrm{kg} / \mathrm{m}^{3}\right)$ \\
\hline 1 & Fly ash & 408.89 & 408.89 \\
\hline 2 & $\begin{array}{l}\text { Activator } \\
\text { Solution }\end{array}$ & 143.11 & 143.11 \\
\hline 3 & $\begin{array}{l}\text { Sodium } \\
\text { Hydroxide }\end{array}$ & 40.89 & 40.89 \\
\hline 4 & Sodium Silicate & 102.22 & 102.22 \\
\hline 5 & Fine Aggregate & 554 & 554 \\
\hline 6 & $\begin{array}{c}\text { Coarse } \\
\text { Aggregate }\end{array}$ & 1293.6 & 1293.6 \\
\hline 7 & $\begin{array}{c}\text { Super } \\
\text { Plasticizer }\end{array}$ & 7.61 & 7.61 \\
\hline
\end{tabular}

\section{V-METHODOLOGY}

\subsection{Mixing}

The fly ash and the aggregates are first mixed together for 3 minutes. The aggregates are prepared in saturated surface dry condition. The alkaline solution is then added to the dry materials and the mixing continued for further about 4 minutes to manufacture the fresh 


\section{International Journal of Innovations in Engineering and Science, www.ijies.net}

concrete. The required quantity of super plasticizer was added as $2 \%$ by mass of fly ash.

\subsection{Casting}

Standard concrete specimen cubes $150 \mathrm{~mm}$ x $150 \mathrm{~mm}$ x $150 \mathrm{~mm}$ was casted and demoulded after 48 hours.

\subsection{Curing}

Two types of curing were used for geopolymer concrete, i.e. Oven curing and Ambient curing. In oven curing, the specimens are oven-cured within $60^{\circ} \mathrm{C}-100^{\circ} \mathrm{C}$ for 24 hours in the oven. Ambient curing of low calcium fly ash based geopolymer concrete is generally recommended. Ambient curing substantially assists the chemical reaction that occurs in the geopolymer paste. Both curing time and curing temperature influence the compressive strength of geopolymer concrete. The curing time varied from 12 to 24 hours. Longer curing time improved the polymerization process resulting in higher compressive strength.

\subsection{Testing}

The compressive strength test on hardened fly ash based geopolymer concrete was performed on standard compression testing machine of $2000 \mathrm{kN}$ Capacity. Totally 44 number of cubical specimens of size $150 \mathrm{~mm}$ $\mathrm{x} 150 \mathrm{~mm} \times 150 \mathrm{~mm}$ was casted and tested for the compressive strength at the age of 7 days, 14days and 28 days.

\section{VI- RESULTS \& DISCUSSION}

The different molarity of $\mathrm{NaOH}(10 \mathrm{M}, 14 \mathrm{M})$ at alkaline liquid to fly ash ratio 0.35 have been selected for testing. The tables 6.1(A) show the compressive strength of geopolymer concrete cubes for different molarities of $\mathrm{NaOH}$ at duration of 7 days, 14 days and 28 days.

Table 6.1- Compressive strength of 10M specimen

\begin{tabular}{|c|c|c|c|c|c|}
\hline \multirow{2}{*}{$\begin{array}{l}\text { Sr. } \\
\text { No }\end{array}$} & \multirow[b]{2}{*}{ Molarity } & \multicolumn{3}{|c|}{ Curing } & \multirow{2}{*}{$\begin{array}{l}\text { Comp } \\
\text { strength } \\
\text { N/mm }\end{array}$} \\
\hline & & Type & Days & $\begin{array}{l}\text { Tem } \\
\text { p }\left({ }^{\circ} \mathrm{C}\right)\end{array}$ & \\
\hline 1 & $14 \mathrm{M}$ & Sun Dry & 7 & $33^{\circ} \mathrm{C}$ & 41.68 \\
\hline 2 & $14 \mathrm{M}$ & Sun Dry & 7 & $33^{\circ} \mathrm{C}$ & 41.03 \\
\hline 3 & $14 \mathrm{M}$ & $\begin{array}{l}\text { Oven } \\
\text { Dry }\end{array}$ & 7 & $75^{\circ} \mathrm{C}$ & 44.34 \\
\hline 4 & $14 \mathrm{M}$ & $\begin{array}{l}\text { Oven } \\
\text { Dry }\end{array}$ & 7 & $75^{\circ} \mathrm{C}$ & 45.11 \\
\hline 5 & $14 \mathrm{M}$ & Sun Dry & 14 & $33^{\circ} \mathrm{C}$ & 58.5 \\
\hline 6 & $14 \mathrm{M}$ & Sun Dry & 14 & $33^{\circ} \mathrm{C}$ & 59.55 \\
\hline 7 & $14 \mathrm{M}$ & Sun Dry & 14 & $33^{\circ} \mathrm{C}$ & 59.91 \\
\hline 8 & $14 \mathrm{M}$ & Oven & 14 & $75^{\circ} \mathrm{C}$ & 61.54 \\
\hline
\end{tabular}

\begin{tabular}{|l|c|c|c|c|c|}
\hline & & Dry & & & \\
\hline 9 & $14 \mathrm{M}$ & $\begin{array}{c}\text { Oven } \\
\text { Dry }\end{array}$ & 14 & $75^{\circ} \mathrm{C}$ & 60.87 \\
\hline 10 & $14 \mathrm{M}$ & $\begin{array}{c}\text { Oven } \\
\text { Dry }\end{array}$ & 14 & $75^{\circ} \mathrm{C}$ & 60.23 \\
\hline 11 & $14 \mathrm{M}$ & Sun Dry & 28 & $33^{\circ} \mathrm{C}$ & 59.80 \\
\hline 12 & $14 \mathrm{M}$ & Sun Dry & 28 & $33^{\circ} \mathrm{C}$ & 61.20 \\
\hline 13 & $14 \mathrm{M}$ & $\begin{array}{c}\text { Oven } \\
\text { Dry }\end{array}$ & 28 & $75^{\circ} \mathrm{C}$ & 62.97 \\
\hline 14 & $14 \mathrm{M}$ & $\begin{array}{c}\text { Oven } \\
\text { Dry }\end{array}$ & 82 & $75^{\circ} \mathrm{C}$ & 66.17 \\
\hline
\end{tabular}

Table 6.2 Compressive strength of 14M specimen

\begin{tabular}{|c|c|c|c|c|c|}
\hline \multirow{2}{*}{$\begin{array}{l}\text { Sr. } \\
\text { No }\end{array}$} & \multirow[b]{2}{*}{ Molarity } & \multicolumn{3}{|c|}{ Curing } & \multirow{2}{*}{$\begin{array}{c}\text { Comp } \\
\text { strength } \\
\text { N/mm }\end{array}$} \\
\hline & & Type & Days & $\begin{array}{l}\text { Tem } \\
\mathbf{p}\left({ }^{\circ} \mathrm{C}\right)\end{array}$ & \\
\hline 1 & $10 \mathrm{M}$ & Sun Dry & 7 & $33^{\circ} \mathrm{C}$ & 33.89 \\
\hline 2 & $10 \mathrm{M}$ & Sun Dry & 7 & $33^{\circ} \mathrm{C}$ & 30.77 \\
\hline 3 & $10 \mathrm{M}$ & $\begin{array}{l}\text { Oven } \\
\text { Dry }\end{array}$ & 7 & $75^{\circ} \mathrm{C}$ & 34.94 \\
\hline 4 & $10 \mathrm{M}$ & $\begin{array}{l}\text { Oven } \\
\text { Dry }\end{array}$ & 7 & $75^{\circ} \mathrm{C}$ & 34.41 \\
\hline 5 & $10 \mathrm{M}$ & Sun Dry & 14 & $33^{\circ} \mathrm{C}$ & 46.45 \\
\hline 6 & $10 \mathrm{M}$ & Sun Dry & 14 & $33^{\circ} \mathrm{C}$ & 47.50 \\
\hline 7 & $10 \mathrm{M}$ & Sun Dry & 14 & $33^{\circ} \mathrm{C}$ & 44.88 \\
\hline 8 & $10 \mathrm{M}$ & $\begin{array}{c}\text { Oven } \\
\text { Dry }\end{array}$ & 14 & $75^{\circ} \mathrm{C}$ & 47.97 \\
\hline 9 & $10 \mathrm{M}$ & $\begin{array}{l}\text { Oven } \\
\text { Dry }\end{array}$ & 14 & $75^{\circ} \mathrm{C}$ & 48.07 \\
\hline 10 & $10 \mathrm{M}$ & $\begin{array}{l}\text { Oven } \\
\text { Dry }\end{array}$ & 14 & $75^{\circ} \mathrm{C}$ & 48.53 \\
\hline 11 & $10 \mathrm{M}$ & Sun Dry & 28 & $33^{\circ} \mathrm{C}$ & 44.23 \\
\hline 12 & $10 \mathrm{M}$ & Sun Dry & 28 & $33^{\circ} \mathrm{C}$ & 45.7 \\
\hline 13 & $10 \mathrm{M}$ & $\begin{array}{c}\text { Oven } \\
\text { Dry }\end{array}$ & 28 & $75^{\circ} \mathrm{C}$ & 52.15 \\
\hline 14 & $10 \mathrm{M}$ & $\begin{array}{c}\text { Oven } \\
\text { Dry }\end{array}$ & 82 & $75^{\circ} \mathrm{C}$ & 48 \\
\hline
\end{tabular}

Table 6.3 Compressive Strength $\mathrm{N} / \mathrm{mm}^{2}$ after 14 days with additional water added

\begin{tabular}{|c|c|c|c|}
\hline \multirow{3}{*}{$\begin{array}{l}\text { Sr. } \\
\text { No }\end{array}$} & \multirow{3}{*}{ Molarity } & \multirow{2}{*}{\multicolumn{2}{|c|}{$\begin{array}{l}\text { Compressive Strength } \\
\mathrm{N} / \mathrm{mm}^{2} \text { after } 14 \text { days } \\
\% \text { of additional water } \\
\text { added in specimen }\end{array}$}} \\
\hline & & & \\
\hline & & $\begin{array}{l}50 \% \text { added } \\
\text { water }\end{array}$ & $\begin{array}{c}100 \% \\
\text { added water }\end{array}$ \\
\hline 1 & $10 \mathrm{M}$ & 11.11 & 2 \\
\hline 2 & $10 \mathrm{M}$ & 9.51 & 2.1 \\
\hline 3 & $10 \mathrm{M}$ & 9.96 & 2.24 \\
\hline
\end{tabular}




\section{International Journal of Innovations in Engineering and Science, www.ijies.net}

\begin{tabular}{|c|c|c|c|}
\hline 4 & $10 \mathrm{M}$ & 6.98 & 1.83 \\
\hline 5 & $14 \mathrm{M}$ & 22.13 & 7.2 \\
\hline 6 & $14 \mathrm{M}$ & 21.6 & 7.91 \\
\hline 7 & $14 \mathrm{M}$ & 19.07 & 8.8 \\
\hline 8 & $14 \mathrm{M}$ & 18.44 & 4.53 \\
\hline
\end{tabular}

\section{VII-CONCLUSIONS}

1. The $\mathrm{Na} 2 \mathrm{SiO} 3$ to $\mathrm{NaOH}$ by mass equal to $1: 2.5$ has resulted into the higher strength geopolymer concrete.

2. The maximum compressive strength obtained for $10 \mathrm{M}$ Oven dry sample was $52.15 \mathrm{~N} / \mathrm{mm} 2$, for Sun dry sample was $45.17 \mathrm{~N} / \mathrm{mm} 2$.

3. The maximum compressive strength obtained for $14 \mathrm{M}$ Oven dry sample was $66.17 \mathrm{~N} / \mathrm{mm} 2$, for Sun dry sample was $59.80 \mathrm{~N} / \mathrm{mm} 2$.

4. The experiment results stated that as the Molarity of Geopolymer Concrete increases there is increase in compressive strength.

5. As the Molarity increases the water to Geopolymer solids ratio decreases.

6. The workability of the geopolymer concrete in fresh state increases with the increase of extra water added to the mix but decreases the compressive strength by $20-30 \%$ overall.

7. Geopolymer concrete tend to show no significant physical change in its properties at normal operating room temperature which is observed in case of normal variety. The complete setting of Geopolymer concrete specimens will take up to 72 hours without any reminisces on the surface on which it is hardened.

8. The use of by-products like Fly ash has gained significant importance because of the requirement of environmental protection and sustainable construction in future.

9. Fly ash, Sodium Hydroxide and Sodium Silicate helps in increasing the mechanical properties on Geopolymer concrete.

\section{REFERENCE}

Fig. 2 -Compressive strength Vs water to geopolymer solids ratio.

- As the molarity of $\mathrm{NaOH}$ solution increases, compressive strength also increases, because as the molarity of $\mathrm{NaOH}$ solution increases water to Geopolymer solids ratio decreases.

- The concrete casted was very stiff because of which it was very hard to compact it so the use of vibrator was done which helped to compact the specimen effectively.

- The experiment performed gave us the results of high strength concrete.

- Effect of water on geopolymer concrete by additional extra water in specimen showed decline in compressive strength of the specimen.

[1] Davidovits, J. (1999). "Chemistry of Geopolymeric Systems, Terminology." Geopolymers 99 International Conference, France.

[2] Mr.G.Hemanaag, Mr.B.S.R.K.Prasad (August 2014),GeoPolymer Concrete using Metakaolin, Fly-Ash and their composition". International Journal of Engineering Research \& Technology (IJERT), Vol.3, Issue-8, August 2014.

[3] Siti Noorbaini Sarmin(May 2016),"Charecterization of FlyAsh/Metakaolin-based GEopolymer Lightweight Concrete Reinforced Wood Particles".Internation Conference on sustainable Built Environment,May-112016.

[4] Bhuvanesh Gawad, Swati Dhurve, Hitesh Vanmali, Mayuresh Patil, "Study of Soil Biotechnology for Waste Water Treatment" SSRG International Journal of Civil Engineering 7.3 (2020): 8-12. 


\section{International Journal of Innovations in Engineering and Science, www.ijies.net}

[5] Dr. Radhakrishna (June 2020)," Geopolymer concrete and the fundamentals of geopolymers" Professor and head of Department of civil engineering, $R V$ college of engineering. 12, June 2020.

[6] Bakharev, T, "Thermal behaviour of geopolymers prepared using class $F$ fly ash an elevated temperature curing", Cement and Concrete Research, 2006.

[7] Mourougane.R, Puttappa C.G., Sashidhar.C, and Muthu, K.U., "Production and Material Properties of high strength Geopolymer concrete", International Conference on Advances in Materials and Techniques in civil Engineering (ICAMAT 2010), Jan-2010, pp. 201- 204.

[8] Bhuvanesh Gawad, Swati Dhurve, "Strutural Assessment of old Building", Journal of Environmental Science, Computer Science and Engineering \& Technology 6(4): September 2017, Pages 466-478.

[9] Naik, H.K., Mishra, M.K., and Beher, B, "Laboratory Investigation and Characterization of Some Coal Combustion Byproducts for their Effective Utilization", 1 st International Conference on Managing the social and Environmental consequences of coal mining in India, New Delhi, November-2007, pp 1-10.

[10] Suresh Thokchom, Partha Ghosh and Somnath Ghosh, "Acid Resistance of Fly ash based Geopolymer mortars" International Journal of Recent Trends in Engineering, Vol. 1, No.6, May -2009, pp. 36-40.

[11] Bhuvanesh Gawad, Swati Dhurve, "Health Safety and Risk Management in Residential Building", International Journal for Scientific Research \& Development, Volume 8, Issue 12, 2021, Pages 101-106.

[12] Vijaya Rangan, B, "Studies on low-calcium fly ash based geopolymer concrete", ICI Journal, Oct-Dec- 2006, pp. 917.

[13] Neetu Singh, Sameer Vyas, Pathak, R.P., Pankaj Sharma, Mahure, N.V., and Gupta, S.L., "Effect of Aggressive Chemical Environment on Durability of Green Geopolymer Concrete". International Journal of Engineering and Innovative Technology (IJEIT), Central Soil and Materials Research Station, Vol. 3, Issue 4, ISSN. 2277-3754, October 2013.

[14] Bhuvanesh Gawad, "Concrete Mix Proportioning: A Short Note", Journal of Environmental Science, Computer Science and Engineering \& Technology 5(3): June 2016, Pages 262-266.

[15] X.J. Song, M. Marosszeky, M.Brungs, R.Munn. "Durability of fly ash based geopolymer concrete against sulphuric acid attack." 10DBMC International Conference on Durability of Building Materials and Components. LYON, France, 17-20April,2005.

[16] Vijay, K, Kumutha ,R, and Vishnuram, B.G., "Influence of curing types on strength of Geopolymer concrete", International Conference on Advances in Materials and Techniques in civil Engineering (ICAMAT 2010), Jan2010, pp. 291-294. 